\title{
Effect of the ruthenium loading and barium addition on the activity of ruthenium/carbon catalysts in carbon monoxide methanation
}

\author{
Elżbieta Truszkiewicz ${ }^{*}$, Wioletta Raróg-Pilecka, Magdalena Zybert, Malwina Wasilewska-Stefańska, \\ Ewa Topolska, Kamila Michalska ${ }^{1}$
}

Warsaw University of Technology, Faculty of Chemistry, Noakowskiego 3, 00-664 Warsaw, Poland

${ }^{1}$ Fertilizer Research Institute, al. Tysiaclecia Państwa Polskiego 13, 24-100 Puławy, Poland

"Corresponding author: e-mail: etruszkiewicz@ch.pw.edu.pl

This article is dedicated to Professor Walerian Arabczyk on the occasion of his 70th birthday.

\begin{abstract}
A group of supported ruthenium catalysts was prepared and tested in methanation of small CO amounts (7000 ppm) in hydrogen-rich streams. High surface area graphitized carbon $\left(484 \mathrm{~m}^{2} / \mathrm{g}\right)$ was used as a support for ruthenium and $\mathrm{RuCl}_{3}$ was used as a $\mathrm{Ru}$ precursor. Some of the $\mathrm{Ru} / \mathrm{C}$ systems were additionally doped with barium $\left(\mathrm{Ba}\left(\mathrm{NO}_{3}\right)_{2}\right.$ was barium precursor). The catalysts were characterized by the chemisorption technique using $\mathrm{CO}$ as an adsorbate. To determine the resistance of the catalysts to undesired carbon support methanation, the TG-MS experiments were performed. They revealed that the barium addition inhibits support losses. The studies of CO methanation (flow reactor, atmospheric pressure) have shown that some of the supported ruthenium catalysts exhibit high activities referred to the metal mass. The catalytic properties of ruthenium proved to be dependent on metal dispersion. Some of the $\mathrm{Ru} / \mathrm{C}$ and $\mathrm{Ba}-\mathrm{Ru} / \mathrm{C}$ systems exhibit higher activity in $\mathrm{CO}$ hydrogenation than the commercial nickel-based catalyst.
\end{abstract}

Keywords: CO methanation, ruthenium catalyst, barium, carbon support.

\section{INTRODUCTION}

Methanation is widely used in industrial plants in the preparation of synthesis gas for ammonia synthesis ${ }^{1}$. The so-called "ultramethanation" is applied in caprolactam plants, where carbon oxide concentrations must be reduced to a few ppm or less ${ }^{2}$. Recently, methanation has also been proposed as an option for cleanup of reformate hydrogen fuels for low-temperature fuel cells ${ }^{2,3}$. Nickel contacts supported on alumina are used in most industrial methanation plants. Consequently, the reactions of $\mathrm{CO}_{\mathrm{x}}$ methanation on nickel are well recognized and described ${ }^{4-6}$. Ruthenium is believed to be more active in $\mathrm{CO}_{\mathrm{x}}$ methanation than nickel ${ }^{2,7}$. The Ru catalysts for low-temperature hydrogenation of carbon oxides to methane are offered for commercial application by Süd Chemie (METH 150) or Alvigo (RKM-3) ${ }^{8}$. Since the chemical formula of commercially available catalyst is a trade secret, Ru catalysts deposited on different supports are extensively studied. There are many reports concerning oxide supports, such as alumina ${ }^{3,9-12}$, titania ${ }^{10,13}$ or sili$\mathrm{ca}^{11,14}$. Also carbon based supports have been described in the literature ${ }^{8,15}$. But information regarding carbon supported $\mathrm{Ru}$ catalyst is significantly modest.

The aim of this work was to establish the effect of the composition of $\mathrm{Ru} /$ carbon catalysts on their activity in carbon monoxide methanation. The basis of these studies was the use of a modified activated carbon as a support for ruthenium and $\mathrm{Ba}$ dopant in the process of obtaining active catalysts for $\mathrm{CO}$ methanation.

\section{EXPERIMENTAL}

The carbon material, denoted throughout the text as C, was used as a support for the catalyst preparation. It was obtained from the commercial activated carbon RO 08 (supplied by the Norit B.V. Company) via high-temperature heating $\left(1700^{\circ} \mathrm{C}, 2 \mathrm{~h}\right.$, helium atmosphere $\left.{ }^{16}\right)$ and a subsequent gasification in a $\mathrm{CO}_{2}$ stream at $855^{\circ} \mathrm{C}$. After the gasification, the mass loss was $19.4 \%$. The BET surface area of the final carbon material equals $484 \mathrm{~m}^{2} / \mathrm{g}$, as determined by the nitrogen physisorption studies. The carbon support was impregnated with acetone solution of ruthenium chloride $\left(\mathrm{RuCl}_{3} \cdot 0.5 \mathrm{H}_{2} \mathrm{O}\right.$, Aldrich), followed by solvent evaporation in a rotary evaporator. The barium nitrate - precursor of the promoter, was introduced to the $\mathrm{Ru} / \mathrm{C}$ systems through impregnation from an aqueous solution at $90^{\circ} \mathrm{C}$ for $16 \mathrm{~h}$. The detailed description of the $\mathrm{Ru} / \mathrm{C}$ and $\mathrm{Ba}-\mathrm{Ru} / \mathrm{C}$ catalysts preparation can be found elsewhere ${ }^{17}$. The ruthenium content in the reduced samples differed form 1 to $25 \mathrm{wt}$.\%. The catalyst symbols include information about: the Ba loading expressed in $\mathrm{mmol} \mathrm{Ba} / \mathrm{g}(\mathrm{Ru}+\mathrm{C})$, the $\mathrm{Ru}$ loading (wt. \%) and carbon support-C, for example: $\mathrm{Ba}(0.44)-\mathrm{Ru}(25) / \mathrm{C}$.

The dispersion of the active phase in the undoped $\mathrm{Ru} / \mathrm{C}$ systems was determined by means of the conventional chemisorption technique (static experiments, ASAP 2020 Micromeritics) using carbon monoxide as an adsorbate at $30^{\circ} \mathrm{C}$. Prior to measurements, the sample was reduced in flowing hydrogen $(80 \mathrm{ml} / \mathrm{min})$ of high purity (>99.9999\%) at $420^{\circ} \mathrm{C}$ for $10 \mathrm{~h}$. The chemisorption data were used for calculating the ruthenium dispersion (FE) and the average sizes of the metal particles $\left(\mathrm{d}_{\mathrm{Ru}}\right)$. The $\mathrm{CO}: \mathrm{Ru}_{\mathrm{s}}=0.6: 1$ stoichiometry and formula proposed by Borodziński and Bonarowska were applied for calculating $\mathrm{FE}$ and $\mathrm{d}_{\mathrm{Ru}}$, respectively ${ }^{15}$.

The TG-MS measurements were performed using a Netzsch STA 449C thermobalance equipped with a quadrupole mass spectrometer (Netzsch QMS 403C). The experiments were conducted using samples of approximately $17 \mathrm{mg}$ of catalyst powder heated up to $500^{\circ} \mathrm{C}$ at the constant rate of $10^{\circ} \mathrm{C} / \mathrm{min}$ in a pure (>99.999 vol\%) $\mathrm{H}_{2}: \mathrm{Ar}=10: 40$ mixture $(50 \mathrm{ml} / \mathrm{min})$. This temperature was maintained for $2 \mathrm{~h}$. The mass change, temperature and selected $\mathrm{m} / \mathrm{e}$ signals were monitored throughout the entire experiment. In order to avoid water condensation all the necessary apparatus parts were kept heated to $250^{\circ} \mathrm{C}$. 
The reaction rate measurements of carbon oxide methanation were carried out in a flow gradientless reactor ${ }^{15}$ operating under atmospheric pressure and supplied with a $\mathrm{CO}-\mathrm{H}_{2}$ mixture $\left(7000 \mathrm{ppm} \mathrm{CO}\right.$ in $\mathrm{H}_{2}$ ). The concentration of methane in the outlet gas was monitored by means of a PU-4500 gas chromatograph equipped with a $\mathrm{CO}_{\mathrm{x}}$ methanizer and a FID detector. The kinetic tests were performed under steady-state conditions at 220, 240 and $270^{\circ} \mathrm{C}$. Re-reduction of the samples preceding the methanation tests was performed in flowing hydrogen $(50 \mathrm{ml} / \mathrm{min})$ at $430^{\circ} \mathrm{C}$ for $4 \mathrm{~h}$.

\section{RESULTS}

The data collected in chemisorption experiments were used for calculating the average size of Ru crystallites in the unpromoted $\mathrm{Ru} / \mathrm{C}$ samples. The obtained $\mathrm{d}_{\mathrm{Ru}}$ values are summarised in Table 1.

Table 1. The average sizes of ruthenium crystallites in the unpromoted $\mathrm{Ru} / \mathrm{C}$ catalysts

\begin{tabular}{|l|c|}
\hline Catalyst symbol & $\mathrm{d}_{\mathrm{Ru}},[\mathrm{nm}]$ \\
\hline $\mathrm{Ru}(1) / \mathrm{C}$ & 1.38 \\
\hline $\mathrm{Ru}(5) / \mathrm{C}$ & 1.64 \\
\hline $\mathrm{Ru}(7.5) / \mathrm{C}$ & 1.78 \\
\hline $\mathrm{Ru}(9) / \mathrm{C}$ & 2.09 \\
\hline $\mathrm{Ru}(15) / \mathrm{C}$ & 3.03 \\
\hline $\mathrm{Ru}(20) / \mathrm{C}$ & 4.09 \\
\hline $\mathrm{Ru}(25) / \mathrm{C}$ & 5.44 \\
\hline
\end{tabular}

There is a clear relation between the ruthenium loading in the catalyst and its dispersion. The higher the ruthenium loading, the higher $\mathrm{d}_{\mathrm{Ru}}$ values (the dispersion decrease). While the Ru content varied by a factor of 25 , only four-time increase of the average crystallite size was observed. It is worth noting that the $\mathrm{Ru}(25) / \mathrm{C}$ sample is characterized by quite small average crystallite size, in spite of a high metal loading. The similar tendency was observed by Kowalczyk et al. ${ }^{15}$.

Since ruthenium is a good catalyst for $\mathrm{CO}$ methanation, it can also catalyze the undesired reaction of carbon support hydrogenation to form methane. That process may cause mechanical damage of the support material and, in consequence, the whole catalyst destruction. In order to examine the effect of ruthenium loading and barium addition on the unfavorable carbon support methanation, the TG-MS experiments were performed. Three series of catalysts were examined. In each group $\mathrm{Ru}$ content was constant: $7.5,15$ or 25 wt.\% $(\mathrm{Ru} / \mathrm{Ru}+\mathrm{C})$, while barium was added at two levels. The selected data, obtained for the $\mathrm{Ru}(25) / \mathrm{C}$ - based serie, is presented in Figure 1 . The results obtained for $\mathrm{Ru}(7.5) / \mathrm{C}$ and $\mathrm{Ru}(15) / \mathrm{C}$ series are qualitatively similar. The first derivative of the mass change (DTG curve) observed when a sample is heated in a flowing mixture of $\mathrm{H}_{2} / \mathrm{Ar}$ is depicted in Figure 1a. There is one peak visible on the DTG line for the Ru(25)/C catalyst. Its minimum was reached in 69th minute of the experiment $\left(110^{\circ} \mathrm{C}\right)$. The mass loss may correspond to the emission of water adsorbed on the surface of the sample, but more probably to the reduction of $\mathrm{RuO}_{2}$ remained on the surface of ruthenium crystallites after passivation. The addition of barium salt causes a small shift of the reduction signal towards higher temperatures $\left(72 \mathrm{~min}, 140^{\circ} \mathrm{C}\right)$. This effect is more pronounced for larger barium amount, i.e. $\mathrm{Ba}(0.66)-\mathrm{Ru}(25) / \mathrm{C}$. The
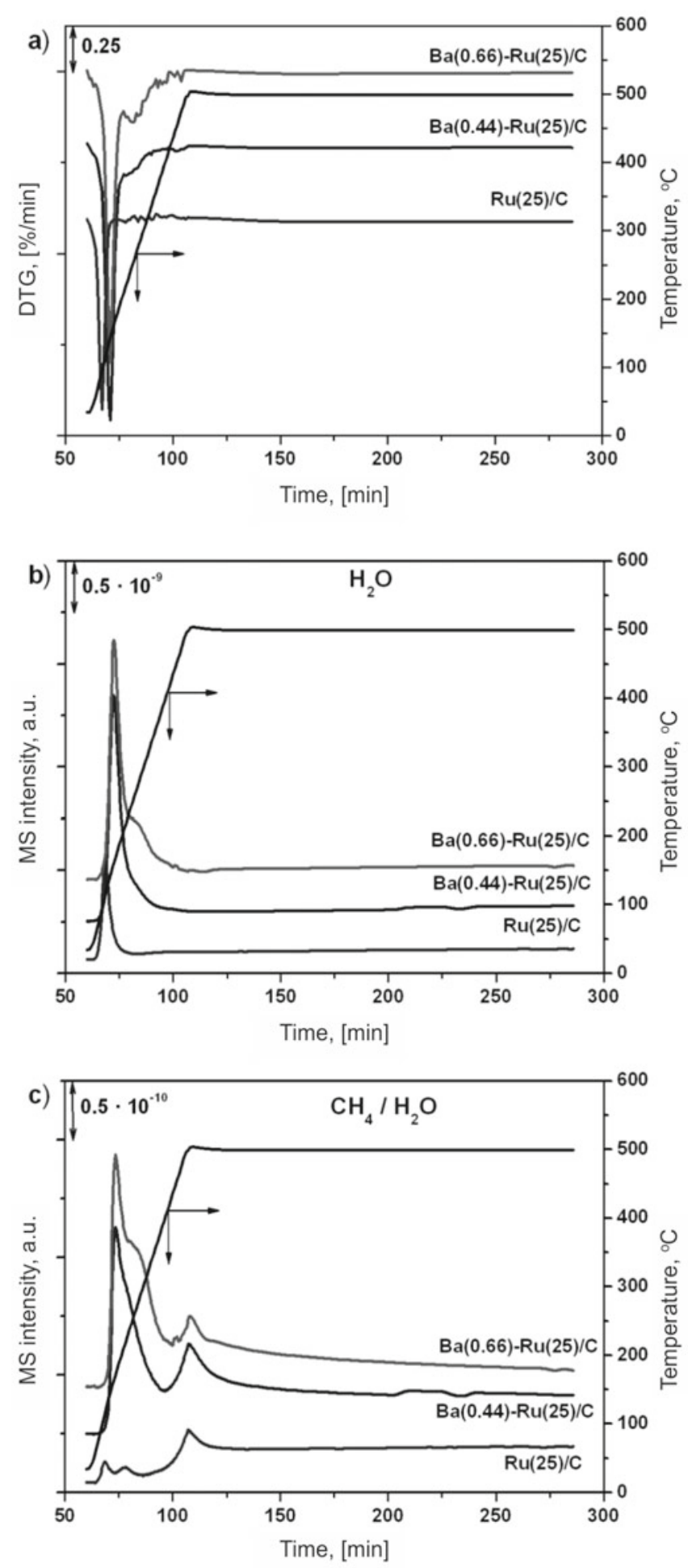

Figure 1. TG-MS measurements: a) DTG curves of the Ru(25)/C and Ba- $\mathrm{Ru}(25) / \mathrm{C}$ catalysts; MS signals: b) m/ $\mathrm{e}=18\left(\mathrm{H}_{2} \mathrm{O}\right)$ vs time , c) $\mathrm{m} / \mathrm{e}=16\left(\mathrm{CH}_{4} / \mathrm{H}_{2} \mathrm{O}\right)$ vs time

mass losses for $\mathrm{Ba}-\mathrm{Ru} / \mathrm{C}$ systems are larger than for $\mathrm{Ru} / \mathrm{C}$ material. It suggests that both ruthenium- and barium compounds start to reduce since 70th minute. Additionally, for barium doped samples the second peak appears close to 80 th $\min \left(230^{\circ} \mathrm{C}\right)$. The mass losses at higher temperatures may come from barium nitrate (the Ba precursor) reduction. Figure $1 b$ shows the amount of evolved water vapour as a function of time. It is clearly visible that water is evolved at the same time as signals on DTG line appear (Fig. 1b). For the Ru(25)/C one peak was observed while two overlapping signals are visible in the case of barium doped materials. The heating of carbon supported catalyst in flowing hydrogen poses a 
risk of a support methanation. The detection of $\mathrm{m} / \mathrm{e}=16$ signals in the mass spectrum (Fig. 1c) are expected to give information about this undesired phenomenon. The signals corresponding to $\mathrm{m} / \mathrm{e}=16$ can appear because of $\mathrm{CH}_{4}$ presence, but also as the second line originated from $\mathrm{H}_{2} \mathrm{O}$. As one can note, the intensity of the spectra presented at Figure 1c is an order of magnitiude lower than that for $\mathrm{H}_{2} \mathrm{O}$ (Fig. 1b). For the $\mathrm{Ru}(25) / \mathrm{C}$ sample three peaks were detected. The first one $(69 \mathrm{~min})$ derives from water evolution, while the signal at $78 \mathrm{~min}$ can be probably assigned to $\mathrm{CH}_{4}$ emission. In the case of the $\mathrm{Ba}-\mathrm{Ru} / \mathrm{C}$ systems, the signals visible in the range 70-90 min are clearly linked with water emission. However, the one at $85 \mathrm{~min}$ has a significant contribution of methane. The third signal appearing on all three samples spectra at about $500^{\circ} \mathrm{C}(108 \mathrm{~min})$ should be assigned to methane production. It is noteworthy that during the isothermal step $\left(\mathrm{T}=500^{\circ} \mathrm{C}\right)$ no methane signals were detected. Moreover, the $\mathrm{m} / \mathrm{e}=16$ lines observed for the $\mathrm{Ba}(0.44)-\mathrm{Ru}(25) / \mathrm{C}$ and $\mathrm{Ba}(0.66)-\mathrm{Ru}(25) / \mathrm{C}$ samples tend to decrease with time of experiment.

The percentage mass losses calculated for the examined samples at isothermal stage are summarised in Table 2. The presented values were calculated on the basis of the TG line level for all barium containing samples and for comparison for respective $\mathrm{Ru} / \mathrm{C}$ materials.

The higher the ruthenium loading in the unpromoted $\mathrm{Ru} / \mathrm{C}$ system, the higher the mass loss at isothermal step $\left(500^{\circ} \mathrm{C}\right)-$ Table 2 . Ruthenium itself, without additives, catalyzes readily the methanation reaction of carbon support ${ }^{18}$. The effect increases with increasing ruthenium content in the material. The introduction of barium inhibits this process. For each group of catalysts with the same $\mathrm{Ru}$ loading, the mass losses assigned to carbon support methanation decrease with increasing barium content. These results are in good agreement with those published by Kowalczyk et al. ${ }^{18}$. In conclusion, the TG-MS studies revealed that barium has an inhibiting effect on unwanted carbon support methanation in $\mathrm{Ru} / \mathrm{C}$ systems.

The most relevant results of carbon monoxide methanation studies are presented in Figures 2 and 3. Figure 2 presents the changes in activity of the catalysts with increasing ruthenium loading. The reaction rate constants were calculated on the basis of data collected under steady-state conditions of pressure $(0.1 \mathrm{MPa})$ and $\mathrm{CO}$ content in the gas phase $(7000 \mathrm{ppm})$ in the temperature range of $220-270^{\circ} \mathrm{C}$.

The relation ln $\mathrm{k}=\mathrm{f}(1 / \mathrm{T})$ demonstrates (Fig. 2), that the activity of the unpromoted $\mathrm{Ru} / \mathrm{C}$ catalysts increases with increasing temperature and $\mathrm{Ru}$ content in the sample. This is in accordance with the literature data ${ }^{\mathbf{8}, 9,15}$.



Figure 2. The activity of the $\mathrm{Ru} / \mathrm{C}$ catalysts in carbon monoxide methanation

These results correlate well with the $d_{R u}$ values obtained from the chemisorption experiments (Table 1). The increasing activity of $\mathrm{Ru} /$ carbon systems with increasing average size of the active phase crystallites suggests that carbon oxide methanation reaction is "structure sensitive". The phenomenon has already been mentioned in the literature ${ }^{15}$. Further studies are necessary to determine the optimum size of ruthenium crystallites in $\mathrm{Ru} /$ carbon systems, which exhibit the highest activity in $\mathrm{CO}$ methanation.

The representative results of methanation studies over barium doped $\mathrm{Ru} / \mathrm{C}$ systems are shown in Figure 3. The data obtained for the commercial Ni-based catalyst (RANG-19) have also been included in Figure 3. The reported rate constants $(\mathrm{k})$ are referred to metal mass (ruthenium for $\mathrm{Ru} / \mathrm{carbon}$ systems or nickel for the industrial catalyst RANG-19) and correspond to fixed CO concentration $(7000 \mathrm{ppm})$ in the gas mixture at $270^{\circ} \mathrm{C}$ and $\mathrm{p}=0.1 \mathrm{MPa}$.

As can be seen in Figure 3, the introduction of $\mathrm{Ba}$ decreases catalytic activity of ruthenium supported on carbon, in general. For $\mathrm{Ru}(25) / \mathrm{C}$ series both barium containing catalysts are less active than the $\mathrm{Ru} / \mathrm{C}$ system. The same effect was observed for $\mathrm{Ru}(7.5) / \mathrm{C}$ series (data not presented). In the case of the $\mathrm{Ru}(15) / \mathrm{C}$ catalyst, a small amount of barium decreases the activity in $\mathrm{CO}$ methanation. Whereas $\mathrm{Ba}(0.59)-\mathrm{Ru}(15) / \mathrm{C}$ system is more active than barium free system.

The influence of barium addition is ambiguous. The role of Ba seems to depend on its loading in the sample and also on ruthenium content. When barium is present

Table 2. Chemical composition of the promoted Ba-Ru/C catalysts; the effect of the presence of barium on the undesired carbon support methanation

\begin{tabular}{|l|c|c|c|}
\hline Catalyst symbol & $\begin{array}{c}\text { Ru loading, } \\
\text { [wt. \%] }\end{array}$ & $\begin{array}{c}\text { Ba loading, } \\
{\left[\mathrm{mmol}_{\mathrm{Ba}} / \mathrm{g}_{\mathrm{C}+\mathrm{Ru}]}\right.}\end{array}$ & $\begin{array}{c}\text { Mass loss at } \\
\text { isothermal stage, [wt. \%] }\end{array}$ \\
\hline $\mathrm{Ru}(7.5) / \mathrm{C}$ & 7.5 & 0 & 1.34 \\
\hline $\mathrm{Ba}(0.37)-\mathrm{Ru}(7.5) / \mathrm{C}$ & 7.5 & 0.37 & 0.91 \\
\hline $\mathrm{Ba}(0.55)-\mathrm{Ru}(7.5) / \mathrm{C}$ & 7.5 & 0.55 & 0.44 \\
\hline $\mathrm{Ru}(15) / \mathrm{C}$ & 15 & 0 & 3.16 \\
\hline $\mathrm{Ba}(0.42)-\mathrm{Ru}(15) / \mathrm{C}$ & 15 & 0.42 & 2.18 \\
\hline $\mathrm{Ba}(0.59)-\mathrm{Ru}(15) / \mathrm{C}$ & 15 & 0.59 & 1.59 \\
\hline $\mathrm{Ru}(25) / \mathrm{C}$ & 25 & 0 & 4.67 \\
\hline $\mathrm{Ba}(0.44)-\mathrm{Ru}(25) / \mathrm{C}$ & 25 & 0.44 & 3.63 \\
\hline $\mathrm{Ba}(0.66)-\mathrm{Ru}(25) / \mathrm{C}$ & 25 & 0.66 & \\
\hline
\end{tabular}




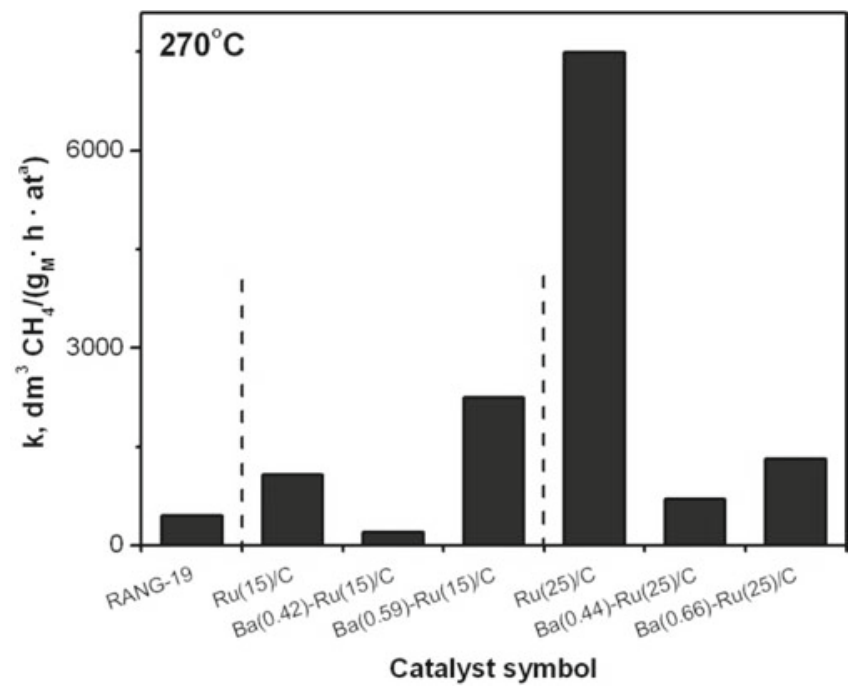

Figure 3. The activity of carbon supported ruthenium catalysts in $\mathrm{CO}$ methanation $(7000 \mathrm{ppm} \mathrm{CO}$ in the gas mixture, $\left.270^{\circ} \mathrm{C}, 0.1 \mathrm{MPa}\right)$

in small amounts, the only positive influence observed was the inhibition of support methanation (see Table 2). But when barium content increases the promoting effect on ruthenium can also appear (see Fig. 3: $\mathrm{Ba}(0.59)-\mathrm{Ru}-$ $(15) / C)$. Such a trend has already been reported in the literature for the caesium promoted $\mathrm{Ru} / \mathrm{Al}_{2} \mathrm{O}_{3}$ catalysts for $\mathrm{CO}$ methanation $^{\mathbf{1 2}}$. The analysis is complicated because of the methodology of the catalytic measurements. In this system methane can be produced in two ways: during desired $\mathrm{CO}$ methanation reaction and unwanted carbon support losses. Further studies are necessary to explain the role of barium in the $\mathrm{Ru} / \mathrm{C}$ materials. It is noteworthy that some of the obtained $\mathrm{Ru} /$ carbon catalysts are more active than the nickel-based industrial system (RANG-19). However, a thermal stability of the above mentioned systems is essential for their practical application. Further experimental work, including stability tests, is necessary for the implementation of the promoted $\mathrm{Ru} / \mathrm{C}$ catalyst to the industrial practice in the future.

\section{CONCLUSIONS}

The activity of $\mathrm{Ru} / \mathrm{C}$ samples increases with increasing $\mathrm{Ru}$ crystallites size. It suggests that $\mathrm{CO}$ methanation on carbon-supported ruthenium catalyst is structure sensitive. On the basis of TG-MS experiments it was revealed that barium inhibits unwanted carbon methanation during interaction with hydrogen. The role of barium is the studied systems is ambiguous. On the one hand, the presence of $\mathrm{Ba}$ decreases the catalytic activity of $\mathrm{Ru}(7.5) / \mathrm{C}$ and $\mathrm{Ru}(25) / \mathrm{C}$ materials. On the other hand, for $\mathrm{Ru}(15) / \mathrm{C}$ contact the promoting effect of barium was observed. Some of the obtained $\mathrm{Ru} /$ carbon and $\mathrm{Ba}-\mathrm{Ru} /$ carbon catalysts are more active than the nickel-based industrial system (RANG-19). Further studies are necessary to resolve an issue of the barium influence on the catalytic properties of $\mathrm{Ru} / \mathrm{C}$ materials and to improve the application potential of ruthenium/carbon systems.

\section{ACKNOWLEDGMENT}

These studies has been financed from the National Science Centre funds within the Research Project No. 2011/01/D/ST8/07157.

\section{LITERATURE CITED}

1. Satterfield, C.N. (1996). Heterogeneous Catalysis in Industrial Practice (2nd ed.), Malabar, USA: Krieger Publishing Company.

2. Kustov, A.L., Frey, A.M., Larsen, K.E., Johannessen, T., Nørskov, J.K. \& Christensen, C.H. (2007). CO methanation over supported bimetallic Ni-Fe catalysts: From computational studies towards catalyst optimization. Appl. Catal. A-GEN 320, 98-104. DOI: 10.1016/j.apcata.2006.12.017.

3. Galetti, C., Specchia, S., Saracco, G. \& Specchia, V. (2010). CO- selective methanation over $\mathrm{Ru}-\gamma \mathrm{Al}_{2} \mathrm{O}_{3}$ catalysts in $\mathrm{H}_{2}$-rich gas for PEM FC applications. Chem. Eng. Sci. 65, 590-596, DOI: 10.1016/j.ces.2009.06.052.

4. Znak, L., Kaszkur, Z. \& Zieliński, J. (2010). Evolution of metal phase in the course of $\mathrm{CO}$ hydrogenation on potassium promoted $\mathrm{Ni} / \mathrm{Al}_{2} \mathrm{O}_{3}$ catalyst. Catal. Lett. 136, 92-95. DOI: 10.1007/s10562-009-0199-1.

5. Kim, S.H., Nam S.W., Lim, T.H. \& Lee, H.I. (2008). Effect of pretreatment on the activity of Ni catalyst for $\mathrm{CO}$ removal reaction by water-gas shift and methanation. Appl. Catal. B-ENVIRON 81, 97-104. DOI: 10.1016/j.apcatb.2007.12.009.

6. Sehested, J., Dahl, S., Jacobsen, J. \& Rostrup-Nielsen, R. (2005). Methanation of CO over nickel: mechanism and kinetics at high $\mathrm{H}_{2} / \mathrm{CO}$ ratios. J. Phys. Chem. B 109, 2432-2438. DOI: $10.1021 / \mathrm{jp} 040239 \mathrm{~s}$.

7. Akin, A.N., Ataman, M., Aksoylu, A.E. \& Önsan, Z.I. (2002). $\mathrm{CO}_{2}$ fixation by hydrogenation over coprecipitated $\mathrm{Co} / \mathrm{Al}_{2} \mathrm{O}_{3}$. React. Kinet. Catal. Lett. 76(2), 265-270. DOI: 10.1023/A:1016579726726.

8. Kowalczyk, Z., Stołecki, K., Raróg-Pilecka, W., Miśkiewicz, E., Wilczkowska, E. \& Karpiński, Z. (2008). Supported ruthenium catalysts for selective methanation of carbon oxides at very low $\mathrm{CO}_{\mathrm{x}} / \mathrm{H}_{2}$ ratios. Appl. Catal. A-GEN 342, 35-39. DOI: 10.1016/j.apcata.2007.12.040.

9. Okuhara, T., Khimura, T., Kobayashi, K., Misono, M. \& Yoneda, Y. (1984). Effects of dispersion in carbon monoxide adsorption and carbon monoxide hydrogenation over alumina-supported ruthenium catalysts. Bull. Chem. Soc. Jpn. 57(4), 938-943. DOI: $10.1246 /$ bcsj.57.938.

10. Londhe, V.P., Kamble, V.S. \& Gupta, N.M. (1997). Effect of hydrogen reduction on the $\mathrm{CO}$ adsorption and methanation reaction over $\mathrm{Ru} / \mathrm{TiO}_{2}$ and $\mathrm{Ru} / \mathrm{Al}_{2} \mathrm{O}_{3}$ catalysts. J. Mol. Catal. A-CHEM 121, 33-44. DOI: 10.1016/S1381-1169(96)00449-9.

11. VanderWiel, D.P., Pruski, M. \& King, T.S. (1999). A kinetic study on the adsorption and reaction of hydrogen over silica-supported ruthenium and silver-ruthenium catalysts during the hydrogenation of carbon monoxide. J. Catal. 188, 186-202. DOI: $10.1006 /$ jcat.1999.2646.

12. Sakakini, B.H. (1997). Temperature-programmed surface reaction (TPSR) of pre-adsorbed carbon $\mathrm{CO}$ and $\mathrm{CO} / \mathrm{H}_{2}$ synthesis over Ru-Cs/ $/ \mathrm{Al}_{2} \mathrm{O}_{3}$ catalysts. J. Mol. Catal. A-CHEM 127, 203-209. DOI: 10.1016/S1381-1169(97)00131-3.

13. Gupta, N.M., Londhe, V.P. \& Kamble, V.S. (1997). Gas-uptake, methanation, and microcalorimetric measurements on the coadsorption of $\mathrm{CO}$ and $\mathrm{H}_{2}$ over polycrystalline $\mathrm{Ru}$ and a $\mathrm{Ru} / \mathrm{TiO}_{2}$ catalyst. J. Catal. 169, 423-437. DOI: 10.1006/ jact.1997.1718.

14. Fujita, S.I. \& Takezawa, N. (1997). Difference in the selectivity of $\mathrm{CO}$ and $\mathrm{CO}_{2}$ methanation reactions. Chem. Eng. J. 68(1), 63-68. DOI: 10.1016/S1385-8947(97)00074-0.

15. Kowalczyk, Z., Stołecki, K., Raróg-Pilecka, W., Miśkiewicz, E., Wilczkowska, E. \& Karpiński, Z. (2008). Catalytic properties of small ruthenium particles supported on carbon. Studies of carbon monoxide methanation. Pol. J. Chem. 82, 607-612.

16. Rosowski, F., Hornung, A., Hinrichsen, O., Herein, D., Muhler, M. \& Ertl, G. (1997). Ruthenium catalysts for ammonia synthesis at high pressures: Preparation, characterization, and power-law kinetics. Appl. Catal. A-GEN 151(2), 443-460. DOI: $10.1016 / \mathrm{S} 0926-860 \mathrm{X}(96) 00304-3$. 
17. Truszkiewicz, E., Raróg-Pilecka, W., Schmidt-Szałowski, K., Jodzis, S., Wilczkowska, E., Łomot, D., Kaszkur, Z., Karpiński, Z. \& Kowalczyk, Z. (2009). Barium-promoted Ru/ carbon catalyst for ammonia synthesis: State of the system when operating. J. Catal. 265, 181-190. DOI: 10.1016/j.cat.2009.04.024.

18. Kowalczyk, Z., Jodzis, S., Raróg, W., Zieliński, J. \& Pielaszek, J. (1998). Effect of potassium and barium on the stability of a carbon-supported ruthenium catalyst for the synthesis of ammonia. Appl. Catal. A-GEN 173(2), 153-160. DOI: $10.1016 / \mathrm{S} 0926-860 \mathrm{X}(98) 00175$. 